\title{
Dynamics of Ethanol Production from Deproteinized Whey by Kluyveromyces marxianus: An Analysis About Buffering Capacity,Thermal and Nitrogen Tolerance
}

\author{
Nathalia Lima Moreira ${ }^{1}$, Leandro Freire dos Santos ${ }^{1,2^{*}}$, Carlos Ricardo Soccol ${ }^{2}$ and Hélio \\ Hiroshi Suguimoto ${ }^{1}$ \\ ${ }^{1}$ Programa de Pós-Graduação em Ciência e Tecnologia de Leite e Derivados; Centro de Pesquisa e Pós- \\ Graduação; Universidade Norte do Paraná; Londrina - PR - Brasil. ${ }^{2}$ Divisão de Engenharia de Bioprocessos e \\ Biotecnologia; Universidade Federal do Paraná; Curitiba - PR - Brasil
}

\begin{abstract}
The production of value-added products could be a valuable option for cheese wastewater management. However, this kind of study cannot just focus alone on getting the final product. This also necessitates studies on the dynamics of bioprocesses. With these as background, the present investigation aimed at evaluating the buffering capacity of deproteinized whey and effect of temperature and nitrogen source on ethanol yields from it. The batch fermentation conditions used to evaluate ethanol production were temperatures $30,35,40^{\circ} \mathrm{C}$ and $\mathrm{pH} 4.5,5.0,5.5,6.0$. To study the influence of nitrogen source on ethanol yield, a design matrix was applied using yeast extract and $\left(\mathrm{NH}_{4}\right)_{2} \mathrm{SO}_{4}$. The final $\mathrm{pH}$ was analyzed to evaluate the buffering capacity. The results showed that the Kluyveromyces marxianus was thermotolerance to produce ethanol at 35 and $40^{\circ} \mathrm{C}$, which was not observed at $30^{\circ} \mathrm{C}$. Results also showed that the deproteinization procedure did not affect the buffering capacity of cheese whey. Finally, higher ethanol production was obtained using yeast extract (3\% v/v). These results could be important for developing low-cost method for industrial production of ethanol from deproteinized whey.
\end{abstract}

Key words: Ethanol fermentation, dairy byproduct, whey management

\section{INTRODUCTION}

The dairy industry generates significant amounts of wastewater, of which, cheese whey $(\mathrm{CW})$ is the most important. It is the liquid resulting from the coagulation of milk and is generated from cheese manufacture (Prazeres et al. 2012; Carvalho et al. 2013). CW management/disposal represents a complex issue from an environmental and engineering point of view due to the high organic load (biological oxygen demand: $35-45 \mathrm{~kg} / \mathrm{m}^{3}$; chemical oxygen demand: $60-80 \mathrm{~kg} / \mathrm{m}^{3}$ ), fats content, and due to high salinity and other suspended solids present in it. Some studies have reported that $\mathrm{CW}$ possessed buffering capacity due to whey proteins (Henriques et al. 2013; Champagne et al. 2014). On the other hand, deproteinized $\mathrm{CW}$ has been widely in order to avoid protein interferences (Rukas et al. 2007; Chatterjee and Guha 2014). Thus, considering that whey protein has a high-buffering capacity and the inclusion of deproteinization processes as an important step to $\mathrm{CW}$ management in order to avoid protein interferences, it could be interesting to evaluate the buffering capacity of deproteinized CW.

The production of value-added products is an attractive option for cheese wastewater

*Author for correspondence: leandrofreire@onda.com.br 
management. Bioactive proteins, ribonucleotides, biodegradable plastics, biogas, hydrogen gas, organic acids, and ethanol have been produced by fermentative processes from cheese wastewater (Koushki et al. 2012; Sharma and Luzinov 2012; Hungaro et al. 2013; Madureira et al. 2013; Powell et al. 2013; Fernandez et al. 2014). Ethanol is an attractive alternative energy source considering the rising costs of fossil fuels in recent times. Moreover, it can play a critical role in reducing greenhouse gas emission (Song et al. 2014). Edible food crops, lignocellulosic agricultural wastes and wastewaters from various industries have been used for ethanol production through fermentation (Isla et al. 2013; Kristensen et al. 2014; Osmani and Zhang 2014). Thus, CW fermentation could be an interesting alternative to produce ethanol because of its high lactose content (Hungaro et al. 2013; Song et al. 2013).

Still on current published reports, $K$. marxianus remains the popular inoculant agent utilized in ethanol fermentation of whey-based media (Table 1) because it presents the thermotolerance, fastest growth rate among eukaryotic organisms, the capacity to assimilate a wide range of sugars (which is an important aspect since different substrates may be combined) and secretion of lytic enzymes (Lane and Morrissey 2010; Signori et al. 2014). However, despite this described thermotolerance, there are lack of studies on evaluating the metabolic tolerance such as nitrogen source influence to obtain the product of interest (end product) at the region of maximum metabolic activity of yeast (RMMA; $\approx \mathrm{pH}: 4.5$ $\left.6.0 ; \mathrm{T}: 30-40^{\circ} \mathrm{C}\right)$, especially in fermentative systems focusing on ethanol production. Furthermore, there is still no absolute consensus about its thermotolerance since previous studies have shown that the final ethanol concentration using free $K$. marxianus could be stable at 30$40^{\circ} \mathrm{C}$ (Le et al. 2013); other studies have shown that ethanol production through fed-batch fermentation using $K$. marxianus at $30-40^{\circ} \mathrm{C}$ has been highest at $30^{\circ} \mathrm{C}$ (Hadiyanto et al. 2014). In the study developed by Húngaro et al. (2013), the authors aimed at evaluating the effect of temperature $\left(30-40^{\circ} \mathrm{C}\right)$ and $\mathrm{pH}(5.0-7.0)$ on the production of ribonucleotides from whey using $K$. marxianus. They found that evaluated temperature/pH range belonging to RMMA (30$40^{\circ} \mathrm{C} ; \quad \mathrm{pH}$ 5.0-7.0) presented altered ribonucleotides yields. These studies showed the necessity to study the effects of temperature and $\mathrm{pH}$ at RMMA on ethanol yields in whey-based medium. Thus, the aim of the present study was to evaluate the buffering capacity of deproteinized $\mathrm{CW}$ (with different initial pHs belonging to RMMA), effect of temperature and the nitrogen source influence (considering its role in protein metabolism) on ethanol yields in whey-based media using $K$. marxianus.

Table 1- Inoculant agents utilized in ethanol fermentation of whey-based media

\begin{tabular}{|c|c|c|c|}
\hline Inoculant agent & $\begin{array}{l}\text { Main fermentation conditions/ } \\
\text { Experimental design }\end{array}$ & Ethanol yield & Reference \\
\hline Lactococcus lactis & $\begin{array}{l}\text { Hydrogen production from } \mathrm{CW} \text { with } \\
\text { ethanol-type fermentation }\end{array}$ & $\begin{array}{l}1.22 \text { mol ethanol } \\
\mathrm{mol}^{-1} \text { lactose }\end{array}$ & (Rosa et al. 2014) \\
\hline $\begin{array}{l}\text { Saccharomyces } \\
\text { cerevisiae }\end{array}$ & $\begin{array}{l}\text { Industrial whey deproteinized }+ \\
\text { Sucrose }\end{array}$ & $\begin{array}{l}\% \text { conversion of substrate } \\
\text { to ethanol of } 76.14 \%\end{array}$ & (Florencio et al. 2013) \\
\hline S. cerevisiae & $\begin{array}{l}\text { Co-immobilization (Saccharomyces } \\
\text { cerevisiae and } \beta \text {-galactosidase }\end{array}$ & $60 \mathrm{~kg} / \mathrm{m}^{3}$ & $\begin{array}{l}\text { (Staniszewski et al. } \\
\text { 2007) }\end{array}$ \\
\hline $\begin{array}{l}\text { Engineered } \\
\text { Escherichia coli }\end{array}$ & Whey powder) & $\begin{array}{l}\text { Enhanced ethanol } \\
\text { production }(17-362 \%)\end{array}$ & (Akbas et al. 2014) \\
\hline $\begin{array}{l}K . \text { marxianus or } \\
K . \text { fragilis }\end{array}$ & Whey permeate supernatant & $2.8 \%(\mathrm{v} / \mathrm{v})$ & (Koushki et al. 2012) \\
\hline \multirow[t]{2}{*}{ Candida kefyr } & $\begin{array}{l}\text { Cheese whey powder }(44 \mathrm{~h} \text { of } \\
\text { fermentation }\end{array}$ & $80.95 \mathrm{~kg} / \mathrm{m}^{3}$ & (Dragone et al. 2011) \\
\hline & Whey permeate supernatant & $2.5 \%(\mathrm{v} / \mathrm{v})$ & (Koushki et al. 2012) \\
\hline $\begin{array}{l}\text { Intergeneric yeast } \\
\text { fusants }(K . \text { marxianus } \\
\text { and S.cerevisiae }\end{array}$ & Cheese whey powder solution & $3.8 \%(\mathrm{v} / \mathrm{v})$ & (Guo et al. 2012) \\
\hline
\end{tabular}




\section{MATERIAL AND METHODS}

\section{Microorganism and growth}

Kluyveromyces marxianus was obtained from the Centre for Postgraduate Studies and Research University of Northern Paraná. It was cultured on a potato dextrose agar (PDA) medium $\left(30^{\circ} \mathrm{C}, \mathrm{pH}\right.$ 5.5). The colonies were inoculated into $100 \mathrm{~mL}$ of nutrient broth and incubated in a $250 \mathrm{~mL}$ Erlenmeyer flask at $30^{\circ} \mathrm{C}$ for $24 \mathrm{~h}$ with shaking at $150 \mathrm{rpm}$ (seed culture). All the reagents used were of the highest grade available unless indicated otherwise. All the media were autoclaved at $121^{\circ} \mathrm{C}$ for $15 \mathrm{~min}$. The cultures were kept at $4^{\circ} \mathrm{C}$ and renewed once in four weeks.

\section{Media and culture conditions}

Kluyveromyces marxianus was inoculated $(5 \%$ $\mathrm{v} / \mathrm{v})$ into $100 \mathrm{~mL}$ of whey supplemented with yeast extract $(12 \mathrm{~g} / \mathrm{L}),\left(\mathrm{NH}_{4}\right)_{2} \mathrm{SO}_{4}(6.0 \mathrm{~g} / \mathrm{L})$, $\mathrm{KH}_{2} \mathrm{PO}_{4}(5.0 \mathrm{~g} / \mathrm{L})$ and $\mathrm{MgSO}_{4} .7 \mathrm{H}_{2} \mathrm{O}(0.6 \mathrm{~g} / \mathrm{L})$ in a $250 \mathrm{~mL}$ Erlenmeyer flask and then incubated at batch fermentation conditions (24 h) (Fig. 1). The whey was obtained from experimental dairy farm of University of Northern Paraná in Tamarana-PR, Brazil. It was deproteinized under the following

conditions: $\mathrm{pH} 4.8$ (adjusted with lactic acid) at $95^{\circ} \mathrm{C}$ followed by centrifugation to remove the protein fraction. All whey-based media were pasteurized $\left(80^{\circ} \mathrm{C}, 30 \mathrm{~min}\right)$.

\section{Batch culture}

The batch fermentation conditions used to evaluate ethanol production at RMMA were temperatures $30,35,40^{\circ} \mathrm{C}$ and $\mathrm{pH} 4.5,5.0,5.5$, 6.0. To study the influence of nitrogen source on ethanol yield, a design matrix was used (Table 2). The final $\mathrm{pH}$ was analyzed to evaluate the buffering capacity.

Table 2 - Design matrix of different nitrogen sources to investigate the effects of the yeast extract/ $\left(\mathrm{NH}_{4}\right)_{2} \mathrm{SO}_{4}$ rates on ethanol production, total nitrogen and total sugars consumption.

\begin{tabular}{cccc}
\hline Runs & $\begin{array}{c}\text { Yeast } \\
\text { extract }(\mathbf{g} / \mathbf{L})\end{array}$ & $\begin{array}{c}\left.\mathbf{N H}_{\mathbf{4}}\right)_{\mathbf{2}} \mathbf{S O}_{\mathbf{4}} \\
(\mathbf{g} / \mathbf{L})\end{array}$ & $\begin{array}{c}\text { Total } \\
\text { nitrogen }(\%)\end{array}$ \\
\hline 1 & 0 & 11.03 & 2.34 \\
2 & 6 & 8.53 & 2.34 \\
3 & 12 & 6 & 2.34 \\
4 & 18 & 3.49 & 2.34 \\
5 & 26.29 & 0 & 2.34 \\
\hline
\end{tabular}

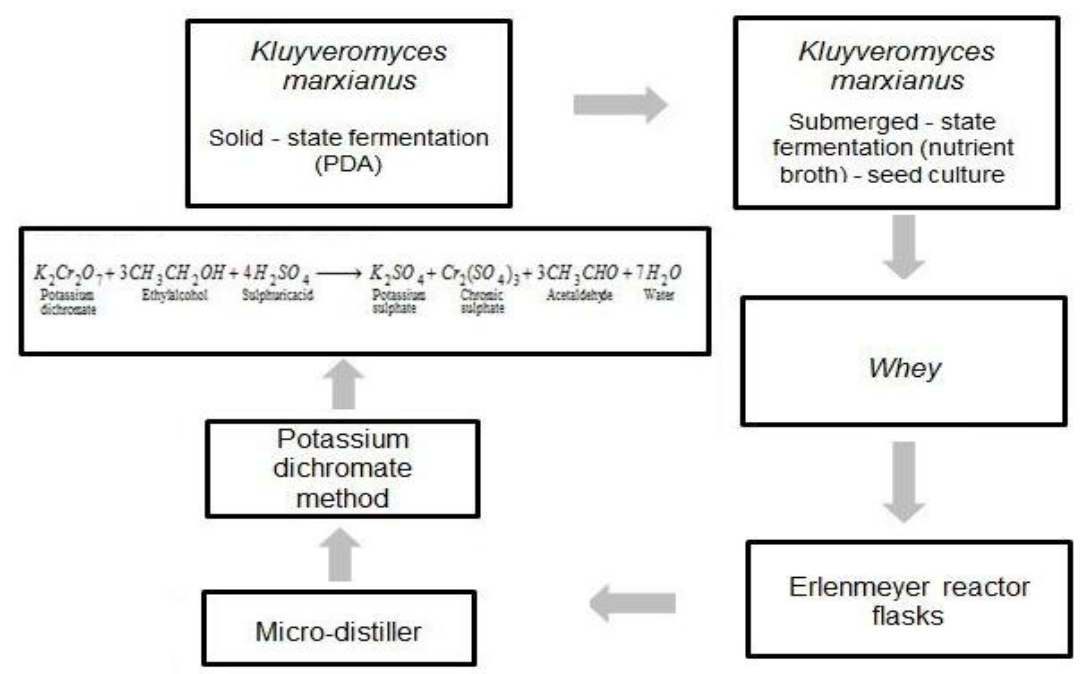

Figure 1 - General experimental design.

\section{Analytical Methods}

Ethanol was determined by potassium dichromate method after isolating from the fermented broth by a microdistillery (Model TE-012, Tecnal $^{\circledR}$, Brazil) (Fig. 1) (Nair and Zuhara 2008). Cell count as colony forming units (CFU) was done following ISO 6611:2004 - Milk and milk products: Enumeration of colony-forming units of yeasts and/or moulds (ISO 2004). The $\mathrm{pH}$ of the wheybased media was determined at $20^{\circ} \mathrm{C}$ by a potentiometer (Model TEC-2, Tecnal ${ }^{\circledR}$, Brazil). Total sugars were quantified according to the phenol-sulfuric acid method (Dubois et al. 1956). Nitrogen content of whey-based media was measured using Kjeldahl method (ISO 2001). 


\section{RESULTS}

Figure 2 shows the profiles of fermentation (percent ethanol and CFU) using temperatures and $\mathrm{pH}$ values relative to RMMA. Results showed similar ethanol yields were for temperatures and $\mathrm{pH}$ used (median ethanol yield $2.78 \pm 0.15 \mathrm{v} / \mathrm{v}$ ) at 35 and $40^{\circ} \mathrm{C}$. Thus, temperature and $\mathrm{pH}$ variation through RMMA did not affect expressively ethanol yields. However, a rough estimate of the number of viable yeast cells, or CFU values, was strongly influenced by $\mathrm{pH}$ variation through RMMA at $30^{\circ} \mathrm{C}\left(3.410^{9}\right.$ to $0.410^{9} \mathrm{CFU} / \mathrm{mL}$ at $\mathrm{pH}$
4.5 and 6.0, respectively): ethanol production was tightly coupled with the growth of yeast cells at this temperature. CFU values at 35 and $40^{\circ} \mathrm{C}$

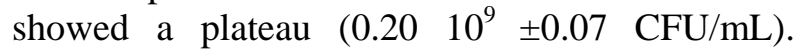
During the fermentation period, a discrete variation of initial and final $\mathrm{pH}$ values were observed at 30,35 and $40^{\circ} \mathrm{C}$ (Fig. 3 A-D). Total sugars were reduced substantially $(94.3 \%$ in general) (Fig. 3E). Therefore, a $35^{\circ} \mathrm{C}$ model at $\mathrm{pH}$ 5.5 was chosen to evaluate the effect of different nitrogen sources (yeast extract and $\left(\mathrm{NH}_{4}\right)_{2} \mathrm{SO}_{4}-$ (Table 2) on ethanol production (Fig. 4).

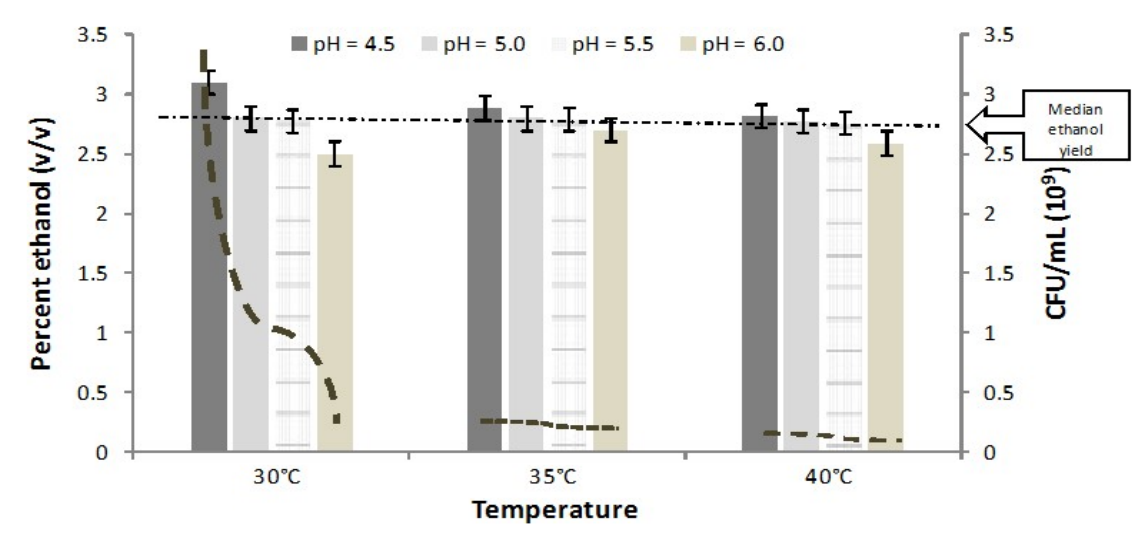

Figure 2 - Ethanol production for the different temperatures $\left(30,35\right.$ and $\left.40^{\circ} \mathrm{C}\right)$ and $\mathrm{pH}(4.5 ; 5.0 ; 5.5$ and 6.0) from K. marxianus. Dashed lines represent data of the cell growth (CFU/mL). Data are reported as mean \pm standard error of the mean (SEM) values of triplicates.
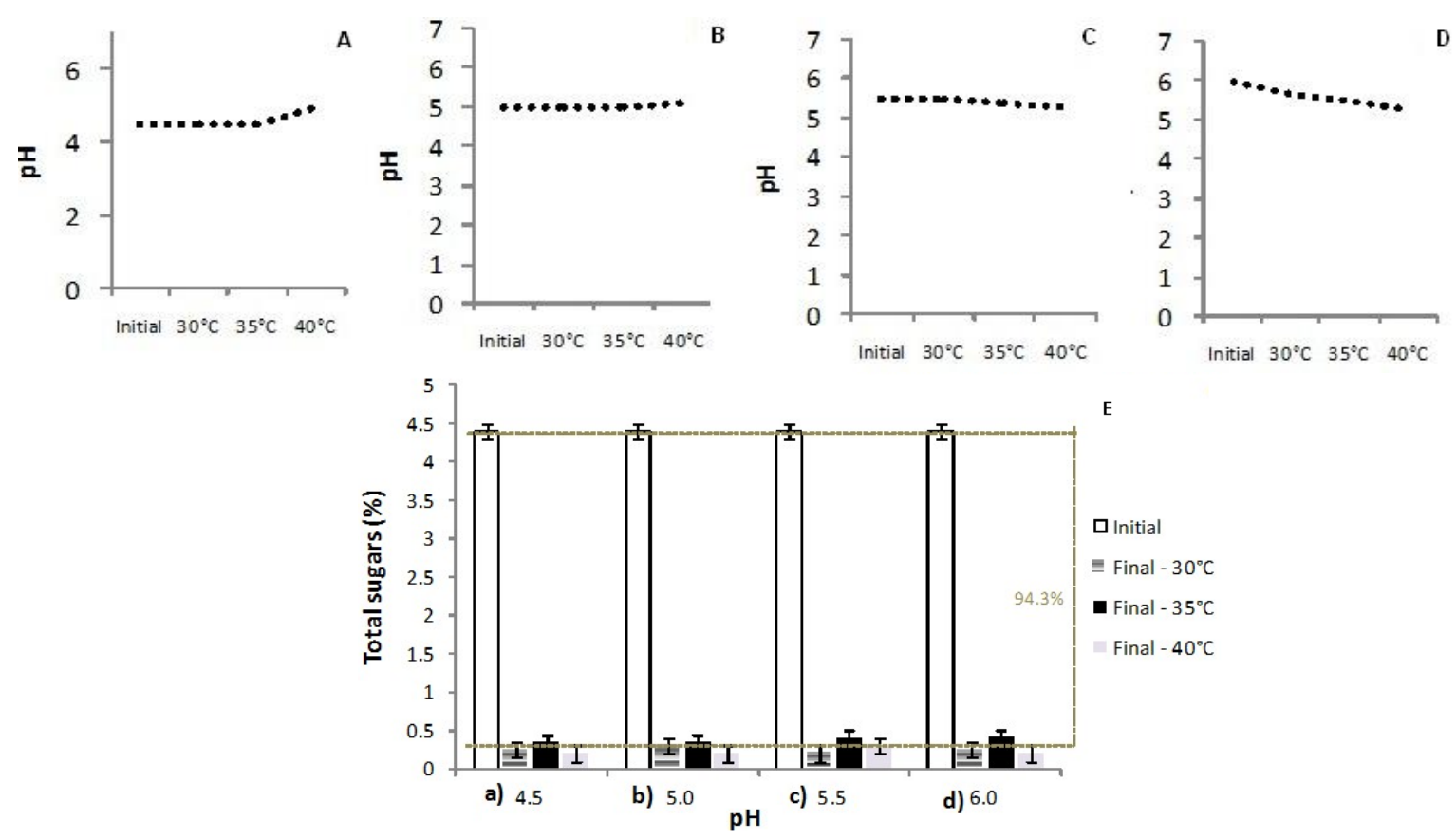

Figure 3 - A-D - Temperature course on $\mathrm{pH}$ variation (after $24 \mathrm{~h}$ at selected temperatures) in basal medium under shake-flask culture conditions. E-Total sugars consumption for the different $\mathrm{pH}(4.5 ; 5.0$; 5.5 and 6.0) from K. marxianus. Dashed lines represent a percent total sugars consumption (based on medians). Data are reported as mean \pm SEM values of triplicates. 


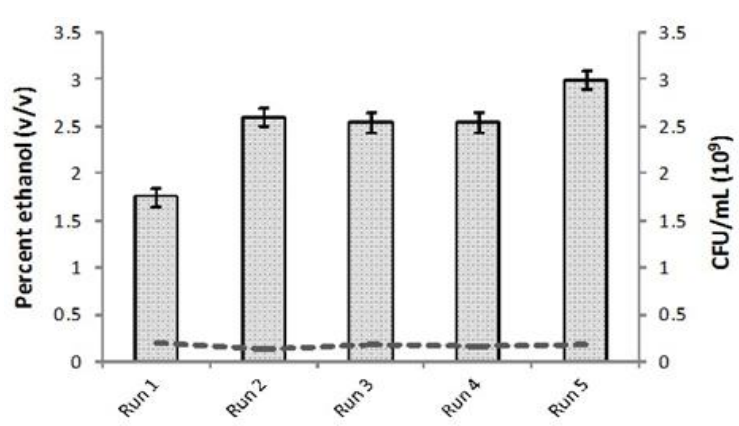

Figure 4 - Ethanol production for the different yeast extract/ $\left(\mathrm{NH}_{4}\right)_{2} \mathrm{SO}_{4}$ rates according to the Table 1. Dashed lines represent data of the cell growth $(\mathrm{CFU} / \mathrm{mL})$. Data are reported as mean \pm SEM values of triplicates.

The results obtained in this experimental design showed that nitrogen sources did not influence CFU values but ethanol production was better at run $5(26.29 \mathrm{~g} / \mathrm{L}$ yeast extract alone) $(3 \% \mathrm{v} / \mathrm{v}$ ethanol yield). The lowest income was observed at run $1\left(11.03 \mathrm{~g} / \mathrm{L}\left(\mathrm{NH}_{4}\right)_{2} \mathrm{SO}_{4}\right.$ alone $)(1.75 \% \mathrm{v} / \mathrm{v}$ ethanol yield).

Figure 5 shows the total nitrogen consumption for the design matrix of different nitrogen sources evaluated. The lowest income regarding ethanol yield (Fig. 5, run 1) consumed only $48 \%$ of total nitrogen while $92 \%$ of total nitrogen was consumed at run 3. Total sugars consumption for the different yeast extract/ $\left(\mathrm{NH}_{4}\right)_{2} \mathrm{SO}_{4}$ concentrations also demonstrated differences (Fig. 6). In particular, run 1 consumed $38.6 \%$, while run 3 reached $86.6 \%$. It was noteworthy to note that both nitrogen and sugar consumption had similar behaviors in the runs that had the best and worst results.

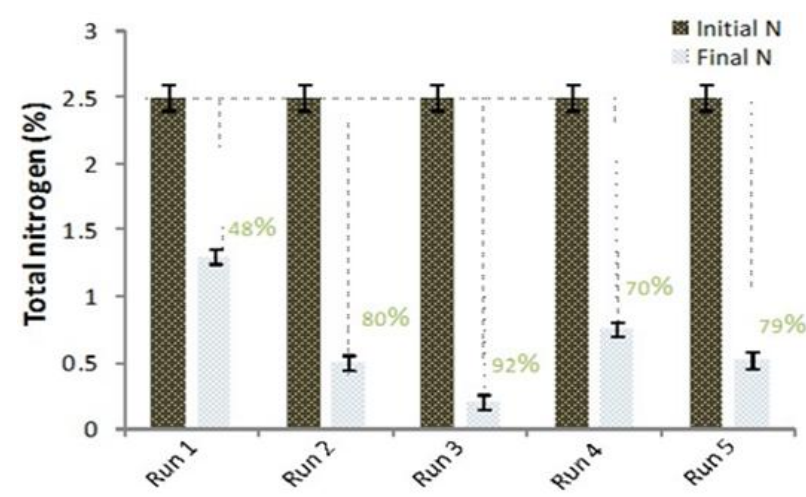

Figure 5 - Total nitrogen consumption for the different yeast extract/ $\left(\mathrm{NH}_{4}\right)_{2} \mathrm{SO}_{4}$ rates according to the Table 1. Dashed lines represent a percent total nitrogen consumption (based on medians). Data are reported as mean \pm SEM values of triplicates.

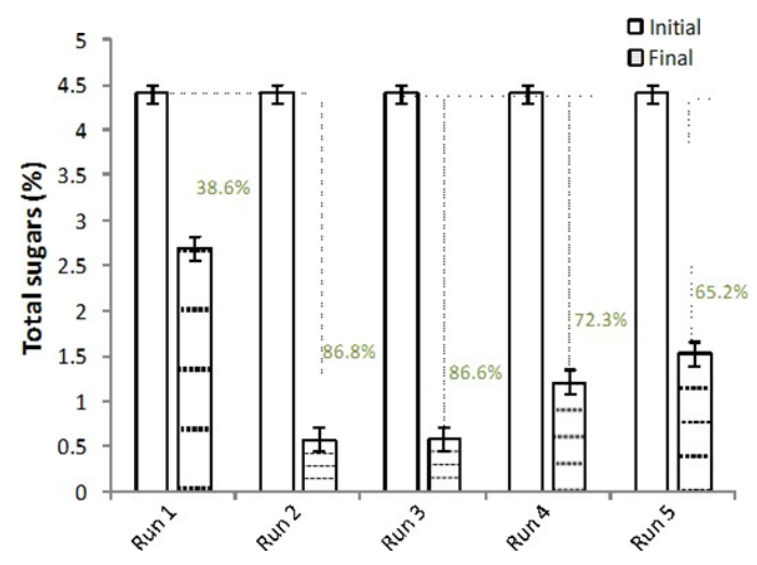

Figure 6 - Total sugars consumption for the different yeast extract/ $\left(\mathrm{NH}_{4}\right)_{2} \mathrm{SO}_{4}$ rates according to the Table 1. Dashed lines represent a percent total sugars consumption (based on medians). Data are reported as mean \pm SEM values of triplicates.

\section{DISCUSSION}

The main objective of this study was to evaluate the buffering capacity of deproteinized $\mathrm{CW}$, effect of temperature and the nitrogen source influence on ethanol yields in whey-based media in submerged fermentation at RMMA. Current interest in this specific experimental design was based on previous studies, which showed higher buffering activity of whey proteins. However, deproteinized $\mathrm{CW}$ has been preferred in design of experiments. Thus, how would be the buffering capacity in these media? Moreover, studies also have shown that the final ethanol concentration using free $K$. marxianus could be stable at $30-40^{\circ} \mathrm{C}$ (Le et al. 2013). However, Hadiyanto et al. (2014) reported that ethanol production through fed-batch fermentation using $K$. marxianus in a temperature range of $30-40^{\circ} \mathrm{C}$ was highest at $30^{\circ} \mathrm{C}$. Therefore, the thermotolerance could be considered a consensus? Table 1 shows the most popular inoculant agents utilized in bioethanol fermentation of whey-based media and ethanol yields.

Initial results showed that growing yeast cells at 35 and $40^{\circ} \mathrm{C}(\mathrm{pH} 4.5-6.0)$ had no expressive effect on the rate of ethanol production (Fig. 2), which showed a thermotolerance to produce ethanol (end product) in these conditions. Thermotolerance has already been described to produce ethanol using $K$. marxianus (Lane and Morrissey 2010; Signori et al. 2014). However, ethanol and biomass productions were influenced at $30^{\circ} \mathrm{C}$ by the changes in $\mathrm{pH}$ (Fig. 2). At this temperature, 
bioethanol was a typical primary metabolite whose production was tightly coupled with the growth of yeast cells (Bai et al. 2008). These results corroborated those demonstrating that the final ethanol concentration, using free $K$. marxianus could be stable at $35-40^{\circ} \mathrm{C}$ yet the system showed instability at $30^{\circ} \mathrm{C}$ (Le et al. 2013; Hadiyanto et al. 2014). Although highest ethanol yield was at $30^{\circ} \mathrm{C}$, this should not be considered due to lack of $\mathrm{pH}$ tolerance and high biomass obtained. It is known that thermotolerance in yeasts is activated not only by high temperatures but also mild heat treatments (Canamas et al. 2008). However, $30^{\circ} \mathrm{C}$ seemed a low temperature to induce thermotolerance, which occurs at 35 and $40^{\circ} \mathrm{C}$.

Based on overall results, the strain was relatively "robust". Robustness focuses on what properties/parameters allow organisms to exhibit and sustain behaviors (in the present case the ethanol production) despite perturbations (behavioral robustness), allowing a greater stress tolerance (Zotta et al. 2013; Leon 2014). This robustness could be due to "metabolic plasticity" (MP). Usually, MP has been used in the studies that address stem cells (Folmes et al. 2012). However, it could be transposed to fermentation dynamics. Thus, MP in fermentation dynamics allows yeast to match its divergent metabolic demands from its end products. In addition, the redox status is greatly influenced by growing yeast cells in distinct carbon sources, which can induce respiratory (ethanol/glycerol) or fermentative (glucose) metabolism. With this in mind, keeping high ethanol levels could have an effect on the intracellular redox, as well as it acts as inductor of respiratory metabolism (RM). RM plays a better role in the energetic metabolism of aerobic organisms (Demasi et al. 2014).

Deproteinized whey medium demonstrated a good buffering capacity when fermented by Rhizopus oryzae to produce chitosan (Chatterjee and Guha 2014). Present study showed no significant differences between the initial and final pHs (Fig. 3A-D). Despite deproteinization procedure, the medium contained phosphate salts and residual whey protein that imparted good buffering activity to the whey medium (data not shown): these considerations have been made by Chatterjee and Guha 2014. Interestingly, buffer substances can be used in cattle nutrition to help animals cope with the adverse effects of high level of dietary carbohydrates, which in turn worsens the ruminal environment (Valdez et al. 2013). This study proved that $K$. marxianus was able to significantly decrease lactose content under all temperature and $\mathrm{pH}$ conditions, which certainly would provide low chemical oxygen demand (COD) and biochemical oxygen demand (BOD) rates (Fig. 3E).

Nitrogen source plays an important role in protein metabolism, which denotes the various biochemical processes responsible for the synthesis of proteins and amino acids, and the breakdown of proteins. A $35^{\circ} \mathrm{C}$ model at $\mathrm{pH} 5.5$ was chosen to evaluate the effect of different forms of nitrogen (yeast extract and $\left(\mathrm{NH}_{4}\right)_{2} \mathrm{SO}_{4}-$ Table 2) on ethanol production. K. marxianus behaved differently under various conditions of nitrogen supply. Higher ethanol production using organic source (run 5, Fig. 4, Table 2) seemed to be due to inherent characteristics of yeast extract (YE), which contained thiamine (Tomaszewska et al. 2014). Interestingly, thiamine has been described as a key component of a fermentation medium that affected ethanol production, and maximized ethanol production in an optimized medium (Dong et al. 2012). Similarly, when compared to total nitrogen consumption (Fig. 5), YE was also among the highest rates of consumption. Results showed that the total nitrogen consumption rate improved using YE plus $\left(\mathrm{NH}_{4}\right)_{2} \mathrm{SO}_{4}$ until $6 \mathrm{~g} / \mathrm{L}$ (Fig. 5). To understand this behavior, it was hypothesized that organic $\mathrm{N}$ could be an additional $\mathrm{N}$ source for the growth and reproduction of microorganism, which was stored in the form of nitrogen compounds (nitrogen storage) (Mauricio et al. 2001). Thus, $K$. marxianus could increase the total nitrogen consumption in this condition (Fig. 5, run 3) to satisfy its demands for nitrogen readily available $\left(\mathrm{NH}_{4}\right)_{2} \mathrm{SO}_{4}$ - and for nitrogen storage, which should remain at constant levels in yeasts.

Biological dynamics of carbon and nitrogen in the process demonstrated that total sugars consumption profile for the different yeast extract/ $\left(\mathrm{NH}_{4}\right)_{2} \mathrm{SO}_{4}$ concentrations matches with total nitrogen consumption profile (Fig. 5 and 6 , run 3). Therefore, there was a harmonic balance between carbohydrate metabolism and protein metabolism -inferred by the proper assimilation of sugar and organic/inorganic N. Certainly the enzymatic machinery of carbohydrate metabolism would be more adequate and efficient with appropriate assimilation of $\mathrm{N}$ (Fig. 6, run 3). In addition, thiamine administration derived from YE could optimize carbohydrate metabolism (Cardenas et al. 2014). 


\section{CONCLUSIONS}

The production of value-added products is an interesting option for cheese wastewater management. Among these value-added products, ethanol has been recognized as a strategic product considering the rising costs of fossil fuels and greenhouse gas emission. The results of this study suggested that $K$. marxianus possessed thermotolerance to produce ethanol at 35 and $40^{\circ} \mathrm{C}$. However, a high amount of biomass was obtained at $30^{\circ} \mathrm{C}$, showing that $30^{\circ} \mathrm{C}$ was not enough to induce thermotolerance, which did not occur at 35 and $40^{\circ} \mathrm{C}$. Results showed that the deproteinization procedure applied to $\mathrm{CW}$ in order to avoid protein interferences did not affect its buffering capacity, possibly due to the residual whey protein and phosphate salts that also could impart good buffering activity to the medium. This buffering capacity, besides being good to the ethanol production, could generate byproducts, which could be applied in cattle nutrition. $K$. marxianus behaved differently under various conditions of nitrogen supply. Higher ethanol production was obtained using YE, which contained thiamine (beneficial effect on ethanol production).

\section{ACKNOWLEDGEMENTS}

The authors are grateful for the support of Coordination of Personnel Improvement Superior Level (CAPES), National Foundation for Development of Private Higher Education (FUNADESP) and Kroton Educational Company (KROTON).

\section{REFERENCES}

Akbas MY, Sar T, Ozcelik B. Improved ethanol production from cheese whey, whey powder, and sugar beet molasses by "Vitreoscilla hemoglobin expressing" Escherichia coli. Biosci Biotech Bioch. 2014; 78(4): 687-694.

Bai FW, Anderson WA, Young, MM. Ethanol fermentation technologies from sugar and starch feedstocks. Biotechnol Adv. 2008; 26(1): 89-105.

Canamas TP, Vinas I, Usall J, Magan N, Solsona C, Teixido N. Impact of mild heat treatments on induction of thermotolerance in the biocontrol yeast Candida sake CPA-1 and viability after spray-drying. J Appl Microbiol. 2008; 104(3): 767-775.
Cardenas CH, Porras JH, Sigarroa ER, Cherit JGD, Lascano JAF. Thiamine administration in critically ill patients to optimize carbohydrate metabolism and reduce insulin requirements. Diabetes Technol Ther. 2014; 16(1): A143-A144.

Carvalho F, Prazeres AR, Rivas J. Cheese whey wastewater: Characterization and treatment. Sci Total Environ. 2013; 445: 385-396.

Champagne CP, Raymond Y, Pouliot Y, Gauthier SF, Lessard M. Effect of bovine colostrum, cheese whey, and spray-dried porcine plasma on the in vitro growth of probiotic bacteria and Escherichia coli. Can J Microbiol. 2014; 60(5): 287-295.

Chatterjee S, Guha AK. A study on biochemical changes during cultivation of Rhizopus oryzae in deproteinized whey medium in relation to chitosan production. Lett Appl Microbiol. 2014; 59(2): 155160.

Demasi M, Hand A, Ohara E, Oliveira CLP, Bicev RN, Bertoncini CA, Netto LES. 20S proteasome activity is modified via S-glutathionylation based on intracellular redox status of the yeast Saccharomyces cerevisiae: Implications for the degradation of oxidized proteins. Arch Biochem Biophys. 2014; 557: 65-71.

Dong HN, Zhao XM, Ma YY, Zhang MH. Optimization of a synthetic medium for ethanol production by xylose-fermenting Zymomonas mobilis using response surface methodology. Chin Sci Bull. 2012; 57(28-29): 3782-3789.

Dragone G, Mussatto SI, Silva JB, Teixeira JA. Optimal fermentation conditions for maximizing the ethanol production by Kluyveromyces fragilis from cheese whey powder. Biomass Bioenerg. 2011; 35(5): 1977-1982.

Dubois M, Gilles KA, Hamilton JK, Rebers PA, Smith F. Colorimetric method for determination of sugar and related substances. Anal Chem. 1956; 28(3): 350356.

Fernandez C, Carracedo B, Martinez EJ, Gomez X, Moran A. Application of a packed bed reactor for the production of hydrogen from cheese whey permeate: Effect of organic loading rate. J Environ Sci Health. 2014; 49(2): 210-217.

Florencio IM, Florentino ER, Da Silva FLH, Martins RS, Cavalcanti MT, Gomes JP. Production of ethanol from industrial whey. Rev Bras Eng Agríc Ambient. 2013; 17(10): 1088-1092.

Folmes CDL, Dzeja PP, Nelson TJ, Terzic A. Metabolic plasticity in stem cell homeostasis and differentiation. Cell Stem Cell. 2012; 11(5): 596-606.

Guo X, Wang R, Chen Y, Xiao D. Intergeneric yeast fusants with efficient ethanol production from cheese whey powder solution: Construction of a Kluyveromyces marxianus and Saccharomyces cerevisiae AY-5 hybrid. Eng Life Sci. 2012; 12(6): 656-661. 
Hadiyanto, Ariyanti D, Aini AP, Pinundi DS. Optimization of ethanol production from whey through fed-batch fermentation using Kluyveromyces marxianus. In Conference and Exhibition Indonesia Renewable Energy \& Energy; 2000.

Henriques MHF, Gomes DMGS, Pereira CJD, Gil MHM. Effects of liquid whey protein concentrate on functional and sensorial properties of set yogurts and fresh cheese. Food Bioprocess Tech. 2013; 6(4): 952963.

Hungaro HM, Calil NO, Ferreira AS, Chandel AK, Da Silva SS. Fermentative production of ribonucleotides from whey by Kluyveromyces marxianus: Effect of temperature and pH. J Food Sci Technology. 2013; 50(5): 958-964.

Isla MA, Comelli RN, Seluy LG. Wastewater from the soft drinks industry as a source for bioethanol production. Bioresource Technol. 2013; 136: 140147.

ISO. (2001). ISO-8968-1, Milk - Determination of nitrogen content. Part 1: Kjeldahl method. International Standard Organization.

ISO. (2004). ISO-6611, Milk and milk products Enumeration of colony-forming units of yeasts and/or moulds. International Standard Organization.

Koushki M, Jafari M, Azizi M. Comparison of ethanol production from cheese whey permeate by two yeast strains. J Food Sci Technol. 2012; 49(5): 614-619.

Kristensen SBP, Thomsen TB, Rasmussen K, Rasmussen LV, Traore O. Cassava as an energy crop: A case study of the potential for an expansion of cassava cultivation for bioethanol production in Southern Mali. Renew Energ. 2014; 66: 381-390.

Lane MM, Morrissey JP. Kluyveromyces marxianus: A yeast emerging from its sister's shadow. Fungal Biol Rev. 2010; 24(1-2): 17-26.

Le HD, Thanonkeo P, Le VVM. Impact of high temperature on ethanol fermentation by Kluyveromyces marxianus immobilized on banana leaf sheath pieces. Appl Biochem Biotechnol. 2013; 171(3): 806-816.

Leon JAF. Robustness as a non-localizable relational phenomenon. Biol Rev. 2014; 89(3): 552-567.

Madureira AR, Soares JC, Amorim M, Tavares T, Gomes AM, Pintado MM, Malcata FX. Bioactivity of probiotic whey cheese: Characterization of the content of peptides and organic acids. J Sci Food Agric. 2013; 93(6): 1458-1465.

Mauricio JC, Valero E, Millan C, Ortega JM. Changes in nitrogen compounds in must and wine during fermentation and biological aging by flor yeasts. $J$ Agr Food Chem. 2001; 49(7): 3310-3315.

Nair TDR, Zuhara M. Kinetic studies on the oxidation of 1-phenyl ethanol and its para-substituted derivatives by potassium dichromate in aqueous acetic acid medium. Asian J Chem. 2008; 20(6): 4388-4392.
Osmani A, Zhang J. Economic and environmental optimization of a large scale sustainable dual feedstock lignocellulosic-based bioethanol supply chain in a stochastic environment. Appl Energ. 2014; 114(SI): 572-587.

Powell N, Broughton A, Pratt C, Shilton A. Effect of whey storage on biogas produced by co-digestion of sewage sludge and whey. Environ Technol. 2013; 34(19): 2743-2748.

Prazeres AR, Carvalho F, Rivas J. Cheese whey management: A review. J Environ Manage. 2012; 110, 48-68.

Rosa PRF, Santos SC, Sakamoto IK, Varesche MBA, Silva EL. Hydrogen production from cheese whey with ethanol-type fermentation: Effect of hydraulic retention time on the microbial community composition. Bioresource Technol. 2014; 161: 10-19.

Rukas T, Mantzouridou F, Boumpa T, Vafiadou A, Goksungur Y. Production of beta-carotene from beet molasses and deproteinized whey by Blakeslea trispora. Food Biotechnol. 2007; 21(1-2): 195-196.

Sharma S, Luzinov I. Water aided fabrication of whey and albumin plastics. J Polym Environ. 2012; 20(3): 681-689.

Signori L, Passolunghi S, Ruohonen L, Porro D, Branduardi P. Effect of oxygenation and temperature on glucose-xylose fermentation in Kluyveromyces marxianus CBS712 strain. Microb Cell Fact. 2014; 13: 51 .

Song H, Dotzauer E, Thorin E, Yan J. Technoeconomic analysis of an integrated biorefinery system for poly-generation of power, heat, pellet and bioethanol. Int J Energ Res. 2014; 38(5): 551-563.

Song YS, Lee HU, Park C, Kim SW. Optimization of lactulose synthesis from whey lactose by immobilized beta-galactosidase and glucose isomerase. Carbohyd Res. 2013; 369: 1-5.

Staniszewski M, Kujawski W, Lewandowska M. Ethanol production from whey in bioreactor with coimmobilized enzyme and yeast cells followed by pervaporative recovery of product - Kinetic model predictions. J Food Eng. 2007; 82(4): 618-625.

Tomaszewska L, Rywinska A, Rymowicz W. High selectivity of erythritol production from glycerol by Yarrowia lipolytica. Biomass Bioenerg. 2014; 64: 309-320.

Valdez ODM, Gama JJS, Tinajero JJM, Medina CEG, De Coss A, Hernandez RO. Buffering capacity of common feedstuffs used in ruminant diets. Rev Colomb Cienc Pec. 2013; 26(1): 37-41.

Zotta T, Guidone A, Lanniello RG, Parente E, Ricciardi A. Temperature and respiration affect the growth and stress resistance of Lactobacillus plantarum C17. J Appl Microbiol. 2013; 115(3): 848-858.

Received: October 22, 2014; Accepted: March 10, 2015 